\title{
Addendum: Direct optical nanoscopy with axially localized detection
}

N. Bourg, C. Mayet, G. Dupuis, T. Barroca, P. Bon, S. Lécart, E. Fort and S. Lévêque-Fort

Nature Photonics 9, 587-593 (2015); published online 3 August 2015; corrected after print 15 October 2015.

The authors wish to acknowledge a highly relevant manuscript that was published during the reviewing process of this Article, which should have been cited:

Deschamps, J., Mund, M., \& Ries, J. 3D superresolution microscopy by supercritical angle detection. Opt. Express 22, 29081-29091 (2014).

The manuscript reports interesting use of 3D DNA-PAINT origami as a ruler for super-resolution imaging. 